\title{
EFFECT OF LEVELS AND SPLITTING OF $N$ FERTILIZATION ON GROWTH, YIELD COMPONENTS, YIELD AND GRAIN QUALITY OF SOME RICE CULTIVARS Oriza sativa $\mathrm{L}$
}

\section{M.F. Abd El-Maksoud}

Plant Production Department, Efficient Productivity Institution, Zagazig Univeristy, Egypt.

\begin{abstract}
Two field experiments were conducted at the experimental farm of the Institute Efficient Productivity, Zagazig University, located at Ghazala village, Sharkia Governorate. The aim of the study was to know effect of nitrogen fertilization levels and its splits on growth and yield of three rice cultivars. The experiments were conducted during 2005 and 2006 summer growing seasons. The tested cultivars were Giza 178, Sakha 103 and Sakha 104. Two nitrogen fertilizer levels 40 and $60 \mathrm{~kg}$ were split and applied at two, three and four equal doses.
\end{abstract}

The most important results were: the rice cultivars differed in their growth, grain yield, yield components and quality characters. Where, Sakha 103 was the superior in most characters and Sakha 104 in the second order.

Increasing nitrogen fertilization levels from 40 to $60 \mathrm{~kg} \mathrm{~N} / \mathrm{fad}$ increased the most yield components which led to significant increase in grain yield/fad. Meantime, rice grain quality was improved significantly with increasing nitrogen fertilizer level.

Increasing of $N$ splitting caused significant increases in growth, yield and yield components. Since four splits was the superior and three splits came in the second rank but two splits treatment was the latter in most characters. Rice grain quality was not affected by nitrogen fertilizer splitting.

Interaction effect between nitrogen fertilizer levels and its splitting was significant on number of unfilled grains/panicle, number of filled grains/panicle and grain yield/fad.

Key words: Rice cultivars, nitrogen fertilization, $\mathrm{N}$ splitting, growth, yield components and grain quality.

\section{INTRODUCTION}

Rice (Oryza sativa, L.) is considered one of the most important source for human food and hard currency earned exportable crop. However, the need to raise its productivity more and more per unit land area is a major goal to meet the increasing demands from this crop. Raising rice production can be achieved through optimizing the agricultural practices such as nitrogen fertilization levels and splitting of nitrogen fertilizer. 
In this regard, many researchers have shown that rice cultivars differ in their growth, grain yield, yield components and quality. This views were reported by Abd El-Wahab (1998), El-Kady et al. (1999), El-Hosary et al. (2000), Omar (2002), ElRewainy et al. (2003), Abd El-Maksoud and Omar (2004) and Sallam (2005).

Bassal Et al. (1996) stated that increasing N-levels from 0, 20, 40 to $60 \mathrm{~kg}$ $\mathrm{N} /$ fad significantly increased plant height, panicle length, panicle grain weight, 100grain weight, straw and grain yield per fad of Gz 1368 cultivar. The same results were reported by Ebaid (2000) Awad (2001) and El Rewainy et al. (2003).

El-Sheref et al. (2004) reported that increasing N-levels to $60 \mathrm{~kg} \mathrm{~N} / \mathrm{fad}$ significantly increased panicle length, panicle grain weight, number of field grains/panicle, 100- grain weight, grain yield and straw yield ton/fad. These results are in agreements with those obtained by Ebaid and Ghanem (2001), Ibrahim (2002), Omar (2002) and Sallam (2005).

Rice quality, hulling \%, milling \% and head rice \% were significantly increased by increasing nitrogen fertilization levels. Similar results were reported by Ebaid and Ghanem (2001), Omar (2002), El-Sheref et al. (2004) and Sallam (2005).

Yield of the newly recommended rice cultivars is not only influenced by nitrogen fertilizer but also by splitting of nitrogen. In this respect, Abd Alla (1996) stated that adding nitrogen fertilizer in two equal doses significantly increased grain yield and most of its components compared with one or three doses. Abd El-Wahab (1999) reported that the highest grain yield and its attributes were recorded when two thirds of the applied nitrogen was incorporated with the dry soil just before transplanting and third one at panicle initiation.

In this regard, many researchers like have Sorour et al. (1988), El-Hosary et al. (2000) Xiao et al. (1999), Surekha et al. (1999), Omar (2002) and Sallam (2005) shown that rice cultivars (growth, yield and quality) responded to splitting nitrogen fertilizer.

El-Hosary et al. (2000) reported that splitting nitrogen to three equal splits increasing milling $\%$, Hulling $\%$ and head rice \% compared with two splits. The same results were reported by El-Refee (1977), Bassal et al. (1996), Sorour et al. (1998), El-Rewaing et al. (2003), Ebaid and Ghonem (2001), El-Kady and Abd El-Wahab (11999) and Sallam (2005).

Therefore, this investigation was carried out in order to study the effect of nitrogen fertilizer levels as well as number of splits of its application on productivity of three rice cultivars.

\section{MATERIALS AND METHODS}

Two field experiments were carried out at Farm of the Institute Efficient Productivity in Ghazala village, Zagazig District, Sharkia Governorate, at 2005 and 2006 summer seasons.

These experiments were conducted to investigate the effect of nitrogen fertilization levels (40 and $60 \mathrm{~kg} \mathrm{~N} / \mathrm{fad}$ ) and nitrogen splitting (two, three and four 
equal splits) on growth, yield, yield components and grain quality of three rice cultivars (Giza 178, Sakha 103 and Sakha 104).

The split-split plot design with three replications in both seasons was followed. The main plots are assigned for rice cultivars. The nitrogen fertilizer levels were allocated in the sub-plots and the nitrogen fertilizer splitting treatments were distributed randomly in the sub-sub plots,

The nursery seedbed was well prepared and fertilized with calcium super phosphate $\left(15.57 \% \mathrm{P}_{2} \mathrm{O}_{5}\right)$ at the rate of $100 \mathrm{~kg} / \mathrm{fad}$. After two weeks from sowing, a rate of $40 \mathrm{~kg} \mathrm{~N} /$ fad was added as urea $(46 \% \mathrm{~N})$.

The seeding rate used was $60 \mathrm{~kg} / \mathrm{fad}$. Rice grains were soaked in running water for 48 hours and inocubated for 48 hours. Thereafter, they were hand broadcasted in May $25^{\text {th }}$ in both seasons. At seven days age, weeds were chemically controlled using Saturn $50 \%$ at the rate of 2 litres dissolved in 100 litres of water/fad which sprayed using knopsack sprayer.

The preceding crop was wheat in both seasons. The permanent field was well prepared and calcium super phosphate $\left(15.5 \% \mathrm{P}_{2} \mathrm{O}_{5}\right)$ was added at the rate of 100 $\mathrm{kg} / \mathrm{fad}$. After one month, seedlings were transplanted, five seedlings per hill, with hill arrangement at $15 \times 15 \mathrm{~cm}$. The plot area was $9 \mathrm{~m}^{2}(3 \times 3 \mathrm{~m})$ including 20 rows/plot. After four days from transplanting weeds were controlled with saturn $50 \%$ at the rate of 2 litres/fad dissolved in 100 litres of water and sprayed using knapsack sprayer.

The tried two $\mathrm{N}$ fertilizer levels were added at equal doses starting from transplanting time and every 15 days later was added at transplanting time and every 15 days later (equal doses) for both tow nitrogen fertilization levels and nitrogen splitting.

The other cultural practices for rice were kept the same as usually recommended in the district. Crop duration for rice cultivars was 125 days for Giza 178 and Sakha 103 and 135 days for Sakha 104.

\section{Studied characters:}

\section{A: Growth :}

In each sub-sub plot ten hills from the second row were marked after transplanting (each hill was thinned to five plants).

At 70 days from transplanting, five marked hills were taken from the second row and the following data were recorded:
1- Plant height $(\mathrm{cm})$.
2 flag leaf area $\left(\mathrm{cm}^{2}\right)$.

3- SPAD values for flag leaf was estimated by using chlorophyll meter (SPAD-50Z, Soil Plant Analysis Development SPAD Section, Minolta Camera Co. Asaka Japan.

\section{B: Yield and yield components:}

At harvest time, ten guarded hills were taken from the two inner rows and the following data were recorded:

1- Panicle length $(\mathrm{cm})$.

2- Panicle grain weight (g).

3- Number of grains/panicle

4- Unfilled grain number/ panicle. 
5- 1000-grain weight (g).

The centeral area of each sub- sub-plot $5.4 \mathrm{~m}^{2}(1.8 \times 2 \mathrm{~m})$ were harvested and the following characters were recorded.

1- Grain yield (ton/fad)

2- Above ground biomass (ton/fad).

\section{C: Grain quality characters:}

Two hundred grams were taken from each treatment and sent to the grain quality Lab of the Rice research and Training Center (RRTC) in Sakha to determine technological characters of grain according to the methods described by Julian (1971) and Khush et al. (1979).

1- Hulling recovery (brown rice) percentage.

2- Milling out percentage.

3- Head rice percentage.

\section{Statistical analysis:}

The Obtained data were subjected to the statistical analysis according to Snedecor and Cochran (1981). Duncan's multiple range test was used for the comparison between means (Dancan, 1955). Means having the same letters are not significantly different.

\section{RESULTS AND DISCUSSION}

Data of the Tables 1-5 show the response of three rice cultivars to $\mathrm{N}$-fertilizer levels and its splits on growth, grain yield, its components and grain quality.

\section{A) Varietal variations:}

Sakha 103 cultivar was the tallest followed by Sakha 104 and then by Giza 178 cultivar. The three cultivars did not show significant variation in SPAD value and flag leaf area as well. Sakha 103 cultivar produced significantly higher panicle number/hill than the other ones, this was true in the $1^{\text {st }}$ season as well as in the combined analysis. Giza 178 cultivar had the tallest spike followed by Sakha 103 and the shortest panicles were produced by Sakha 104. The latter cultivar had lower number of unfilled grains than Giza 178 as shown in the combined analysis Giza 178 was more efficient in producing more filled grains /panicle than the other two. Grain weight of the three cultivars showed also significant variation. The heaviest grains were of Sakha 103, followed by Sakha 104 and the lightest grains were of Giza 178. The significantly light grains of Giza 178 could not be compensated for by increasing number of filled grain resulting in lowest grain weight/panicle. The two Sakha cultivars outyielded Giza 178. Their yields were significantly higher than that of Giza 178. Though Giza 178 produced more number of filled grain, yet its light grains was the main reason of its yield deteriorily. Generally, these varietal variations were due to differences in their genetical make up. These results are in agreement with those obtained by El-Kady et al. (1999), El-Hosary et al. (2000), Omar (2002), El-Rewainy et al. (2003), Abd El-Maksoud and Omar (2004) and Sallam (2005). 
Tab 1-5 


\section{B- Effect of increasing N-level:}

Increasing nitrogen fertilizer level from 40 to $60 \mathrm{~kg} \mathrm{~N} / \mathrm{fad}$ caused affect the other characters i.e. plant height, flag leaf area, number of panicle/hill, panicle length, 1000 -grain weight and grain weight/panicle all were not affected by increasing the nitrogen level. The grain yield was increased significantly. The number of filled grain was increased by $3.3 \%$ while number of unfilled grains was decreased by $10.4 \%$. These two characters may be the reason of increase grain yield by $5 \%$. The same results were reported by Ebaid (2000), Awad (2001), Ibrahim (2002), Omar (2002), El-Shereif et al. (2004) and Sallam (2005).

\section{C-Number of splits of nitrogen fertilizer :}

Plant height as measurement of vegetative growth was affected by splitting of $\mathrm{N}$-fertilizer. Early application of $\mathrm{N}$-fertilizer favoured plant height and this could seen when two splits (ended at 15 days after transplanting) gave the tallest plants than three splits (ended at 30 days). SPAD value (monitering chlorophyll content) was benefited by splitting to 4 doses. Flag leaf area, number of panicles/hill and panicle length were not influenced by the splitting process. Number of unfilled and filled grains/panicle were affected significantly. The former was reduced and the latter was increased by delaying $\mathrm{N}$-fertilizer application likewise, the 1000-grain weight was favoured by such delay. Panicle grain weight was affected significantly by the splitting process. It seems that splitting $\mathrm{N}$-application to four doses i.e. delaying to $\mathrm{N}$-application from 15 days (two splits), to 30 days (three splits) and to 45 days (four splits) provided the rice plants with nitrogen throughout the vegetative growth period (all 75 days). This may explain the favour effect of splitting $\mathrm{N}$-fertilizer on these yield attributing traits. These effects led the grain yield and Above ground biomass to be affected positively by splitting the nitrogen fertilizer to 3 or 4 doses. Similar results were obtained by Abd El-Wahab (1999) El-Hosary et al. (2000) Ebaid and Ghanem (2001) Omar (2002) and Sallam (2005).

\section{Effect of nitrogen fertilizer levels and splitting on grain quality of rice cultivars:}

Sakha 103 and Sakha 104 cultivars gave better milling head rice percentages than Giza 178. This was due to the gentical make up of the three cultivars. These results are in agreement with those reported by El-Hosary et al. (2000) El-Rewainy et al. (2003) and Abd El- Maksoud and Omar (2004).

Increasing $\mathrm{N}$-fertilizer level from 40 to $60 \mathrm{~kg} \mathrm{~N} /$ faddan caused significant increase in head rice \%. The other to characters were not (as pooled data) influenced by the increase $\mathrm{N}$-fertilizer level. The same results were obtained by Ebaid (2000), Awad (2001), El-Sheref et al. (2004) and Sallam (2005).

Finally increasing number of splits of $\mathrm{N}$-fertilizer application had no effect of rice on grain quality.

\section{E. Effect of interactions:}

The data in Table 6 show the significant interaction effect of N-levels and number of splitting of $\mathrm{N}$-fertilizer on number of unfilled grains/panicle. 
Table 6: Interaction effect between nitrogen fertilizer levels and nitrogen fertilizer splitting on unfilled grain/panicle(combined data)

\begin{tabular}{cccc}
\hline Nitrogen fertilizer levels & \multicolumn{3}{c}{ Nitrogen fertilizer splitting } \\
\cline { 2 - 4 } & $\mathbf{S}_{\mathbf{1}}$ & $\mathbf{S}_{\mathbf{2}}$ & $\mathbf{S}_{\mathbf{3}}$ \\
\hline $\mathbf{4 0} \mathbf{k g ~ N} / \mathbf{f a d}\left(\mathbf{N}_{\mathbf{1}}\right)$ & $\mathrm{A}$ & $\mathrm{B}$ & $\mathrm{B}$ \\
& $18.30 \mathrm{a}$ & $13.53 \mathrm{a}$ & $13.71 \mathrm{a}$ \\
\hline $\mathbf{6 0} \mathbf{k g ~ N} / \mathbf{f a d}\left(\mathbf{N}_{\mathbf{2}}\right)$ & $\mathrm{A}$ & $\mathrm{B}$ & $\mathrm{C}$ \\
& $16.37 \mathrm{~b}$ & $12.94 \mathrm{~b}$ & $11.48 \mathrm{~b}$ \\
\hline
\end{tabular}

The higher N-level reduced number of unfilled grains/panicle irrespective to the number of splits. On the other direction, splitting of $40 \mathrm{~kg} \mathrm{~N} /$ fad more than two doses reduced the unfilled grain number, splitting of $60 \mathrm{~kg} \mathrm{~N} /$ fad more than three doses gave the least unfilled grain number (Table 6).

Number of filled grains showed differential response to number of splits of Nfertilizer. Three splits favoured to Giza 178 while four splits favoured both Sakha cultivars. In the other hand, Giza 178 had the higher number of filled grains /panicle than the other two irrespective to the number of splits (Table 7).

Table 7: Interaction effect between rice cultivars and nitrogen fertilizer splitting on number of filled grains/panicle (combined data).

\begin{tabular}{cccc}
\hline Rice cultivars & \multicolumn{3}{c}{ Nitrogen fertilizer splitting } \\
\cline { 2 - 4 } & $\mathbf{S}_{\mathbf{1}}$ & $\mathbf{S}_{\mathbf{2}}$ & $\mathbf{S}_{\mathbf{3}}$ \\
\hline $\mathbf{C V}_{\mathbf{1}}$ & $\mathrm{C}$ & $\mathrm{A}$ & $\mathrm{B}$ \\
& $118.97 \mathrm{a}$ & $125.73 \mathrm{a}$ & $124.60 \mathrm{a}$ \\
\hline $\mathbf{C V}_{\mathbf{2}}$ & $\mathrm{C}$ & $\mathrm{B}$ & $\mathrm{A}$ \\
& $112.53 \mathrm{~b}$ & $121.64 \mathrm{~b}$ & $123.98 \mathrm{a}$ \\
\hline $\mathbf{C V}_{\mathbf{3}}$ & $\mathrm{C}$ & $\mathrm{B}$ & $\mathrm{A}$ \\
& $113.25 \mathrm{~b}$ & $118.70 \mathrm{c}$ & $121.27 \mathrm{~b}$ \\
\hline
\end{tabular}

The three cultivars showed different behaviors in their grain yield will response to changing the number of doses of $\mathrm{N}$-fertilizer as seen in Table 8 .

Table 8: Interaction effect between rice cultivars and nitrogen fertilizer splitting on grain yield (t/fad) (combined data).

\begin{tabular}{cccc}
\hline Rice cultivars & \multicolumn{3}{c}{ Nitrogen fertilizer splitting) } \\
\cline { 2 - 4 } & $\mathbf{S}_{\mathbf{1}}$ & $\mathbf{S}_{\mathbf{2}}$ & $\mathbf{S}_{\mathbf{3}}$ \\
\hline $\mathbf{C V}_{\mathbf{1}}$ & $\mathrm{C}$ & $\mathrm{B}$ & $\mathrm{A}$ \\
& $2.659 \mathrm{a}$ & $3.103 \mathrm{~b}$ & $3.714 \mathrm{~b}$ \\
\hline $\mathbf{C V}_{\mathbf{2}}$ & $\mathrm{C}$ & $\mathrm{B}$ & $\mathrm{A}$ \\
& $2.572 \mathrm{a}$ & $3.611 \mathrm{a}$ & $4.069 \mathrm{a}$ \\
\hline $\mathbf{C V}_{\mathbf{3}}$ & $\mathrm{B}$ & $\mathrm{A}$ & $\mathrm{A}$ \\
& $2.624 \mathrm{a}$ & $3.745 \mathrm{a}$ & $4.080 \mathrm{a}$ \\
\hline
\end{tabular}


As seen, the Sakha cultivars outyielded Giza 178 cultivar when the doses increased to three or four times and all the three cultivars gave statistically equal yields when the $\mathrm{N}$-fertilizer was divided to only two doses. On the other direction, Sakha 103 was not affected by increasing N-splitting more than three doses while the other two cvs responded positively to increasing number of doses from three to four times.

\section{REFERENCES}

Abd El-Maksoud M. F. and A. E. A. Omar (2004). Determination of optimum hill spacing for some rice cultivars (Oryza sativa L. ). J. Product.\& Dev., 9 (2): 299313.

Abd El-Wahab, A. E. (1998). Physiological behavior of some Egyptian rice cultivars under different nitrogen levels. Egypt. J. Appl. Sci., 13 (4): 114-129.

Abdo, M. A. D. (1994). Effect of some agricultural practices on growth and yield of rice. M. Sc. Thesis, Fac. Agric., Mansoura Univ.

Duncan, D. B. (1955).Multiple range and multiple F-test. Biometrics, 11: 1-24.

Ebaid, R. A. (2000). Rice productivity as affected by integration of organic nitrogen fertilizers. J. Agric. Sci. Mansoura Univ., 25 (12): 7357-7365.

Ebaid, R. A. and S. R. Ghonem (2001). Effect of nitrogen and potash fertilizers on the productivity of Sakha 101 rice cultivar. J. Agric. Sci. Mansoura Univ., 26 (4): 1833-18/40.

El-Aidy, A. Nadia; M. I. El-Emery; A. E. Draz and A. T. Badawi (2000). Chemical and morphological characters of some local rice genotypes. Egypt. J. Agric. Res. 78 (12): 693-716.

El-Hadidi, E. N.; Z. M. El-Sirafy; M. A. Ibrahim and E. A. Moursi (2002). Nutrients uptake by rice plant and grain protein content as affected by irrigation depth and rice cultivars grown in Nile Delta. J. Agric. Sci. Mansoura Univ., 27 (8): 5657-5665.

El-Hosary, A. A. ; M. R. Gomaa, A. T. Badawi and I. H. Abou El-Darag (2000). Effect of time and method of nitrogen application with transplanted and broadcasted rice on yield and quality characteristics. Proc. $9^{\text {th }}$ Conf. Agron., Minfiya Univ. 1-2 Sept., 151-165.

El-Kady, A. A. and A. E. Abd El-Wahab (1999). Nitrogen fertilizer management and its effect on growth, yield and grain quality of some Egyptian rice cultivars. Egypt. J. Appl. Sci., 14 (7): 24-35.

El-Refaee, I. S. (1997). Effect of some irrigation treatments on growth and yield of rice. M. Sc. Thesis, Fac. Agric., Kafr El-Sheikh, Tanta Univ. Egypt.

El-Rewainy, I. M.; S. A. Ghanem; I.S. El-Refaee and W. H. El-Kallawy (2003). Effect of seeding rate and nitrogen level on productivity of broadcast seeded Sakha 101 and Sakha 102 rice cultivars. Proc. 10 ${ }^{\text {th }}$ Conf. Agron., Suez Canal Univ., Fac. Environ. Agric. Sci., El-Arish, Egypt.

El-Shahat, R. M.; A. S. Osman and H. M. Seyam (2002). Rice response to nitrogen, Azolla and Azospirilum fertilization. Egypt. J. Appl. Sci., 17(3): 86-93. 
Fageria, N. K.; V. C. Baligar and C. A. Jones (1997). Growth and mineral nutrition to field crops. Rice: 283-344, Marcel Dekker, Inc., 270 Madison Avenue, New York, USA.

Helal, A. A. Z. (2000). Response of some cultivars to different space among hills and rows under saline soil conditions. M.Sc. thesis, Fac. Agric. Mansoura Univ. , Egypt.

Ibrahim, E. M. (2002). Effect of preceding winter crops and biological fertilization on growth and yield of rice under different levels of nitrogen fertilization. $J$. Agric. Sci. Mansoura Univ., 27 (12): 8021-8032.

Juliano, B. D. (1971). A simplified assay for milled rice amylase. Cereal Sci. Today, 16: $334-360$.

Khush, G. S.; C. M. Paule and N. M. Dels-Cruze (1979). Rice grain quality evaluation and improvement at IRRI. Proc. Workshop on Chemical Aspects of Rice grain Quality. IRRI, Manila, Philipines.

Omar, A. E. A. (2002). Rice fertilization under saline soil conditions. Ph. D. Thesis. Fac. Agric. Zagazig Univ., Egypt.

Sallam, S. T.M. (2005). Studies on yield potentiality of Giza 177 and Sakha 101 rice cultivars under the effect of biofertilization and splitting of nitrogen. $\mathrm{Ph}$. D. Thesis Fac. Agric. Zagazig Univ., Egypt.

Snedecor, G. W. and W. G. Cochran (1967). Statistical Methods. $6^{\text {th }}$ ed Iowa State Univ. Press Ames Iwoa, USA.

Sorour, F. A.; M. E. Mosalem; F. N. Mahrous and I. S. El-Refaee (1998). Effect of irrigation intervals and splitting of nitrogen on growth, yield and quality of rice.. J. Agric. Res., Tanta Univ., 24 (1): 60-75.

Surekha, K.; M. N. Reddy and R. M. Kumar (1999). Yield attributes and yields of rice (Oryza sativa) hybrids as influenced by nitrogen sources and its splits application. Indian J. Agron., 44 ( 1): 80-88.

Xoao Lizhong; lizhili; Zhong Jianguo; Ding Chunhua (1999). Effect of nitrogen application during early growth stage in the tillers and the tiller-panicle turnover rate of two line hybrid rice. Journal of South China, Agric. Univ. , 20 (3): 10-14. 


\section{تأثيرمستوبلت وتجزئ النسميد النيتروجيف علي النمو والمحصط ومكوناته

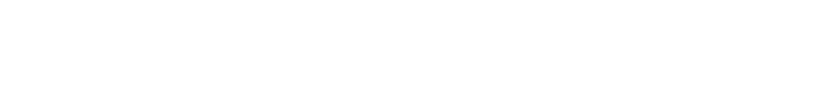

\section{مجدي فتهي عبدالةصود قم الإنتاج النباتي (محاصل) -معهد الهلية الإنتاجية - جامعة الزقازق}

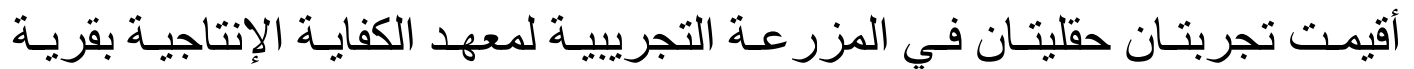

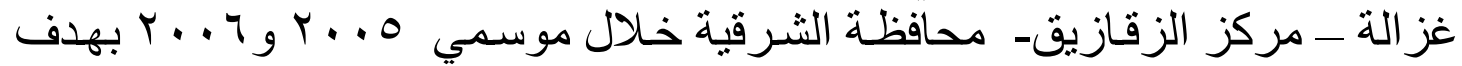

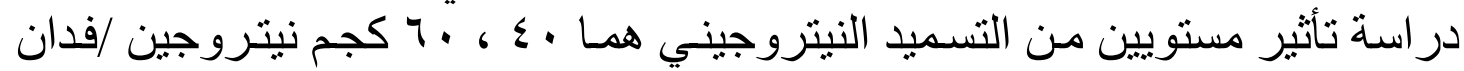

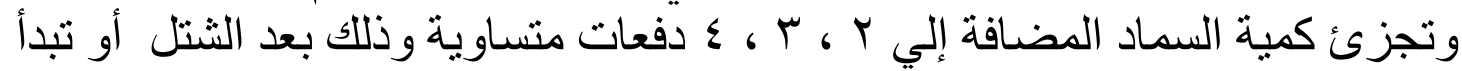

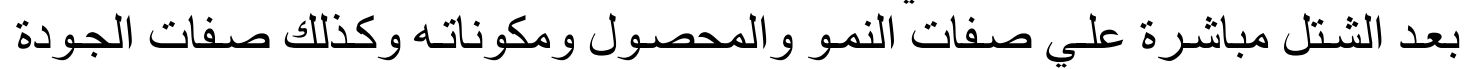

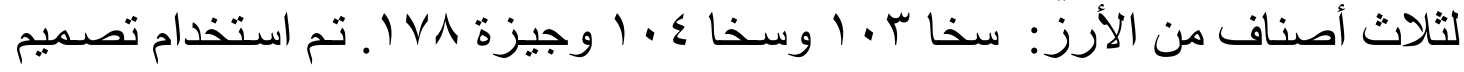

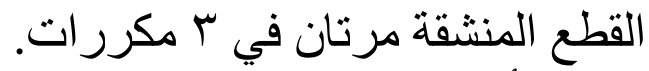

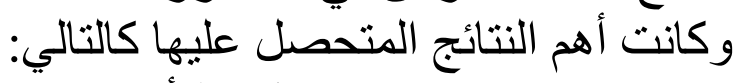

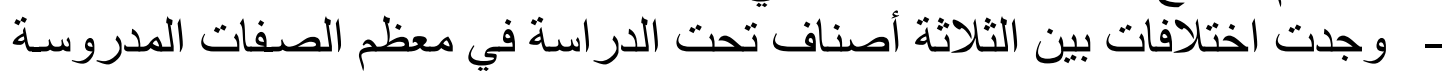

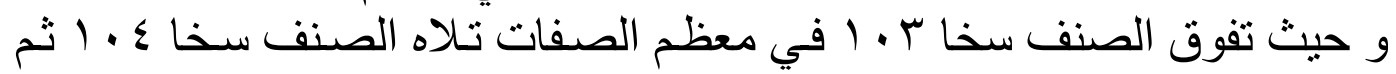

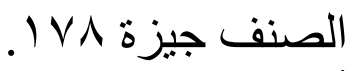

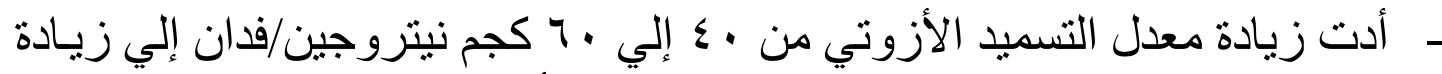

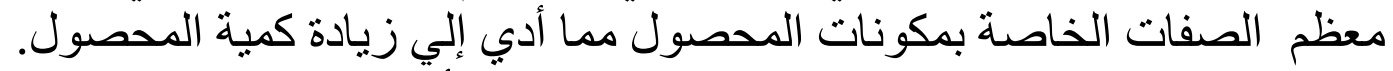

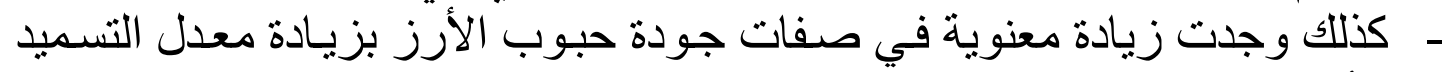

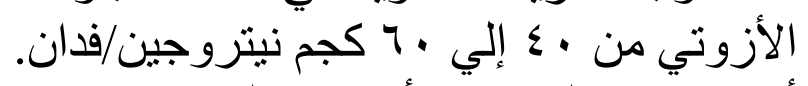

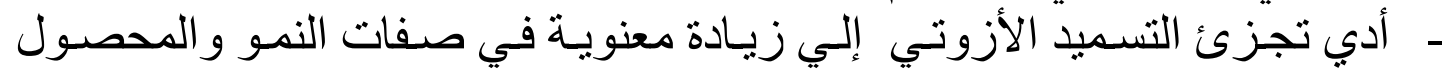

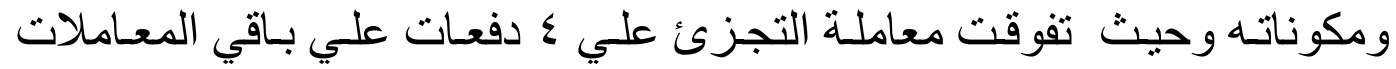

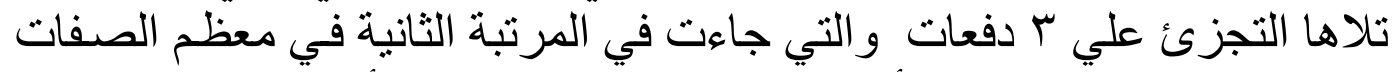

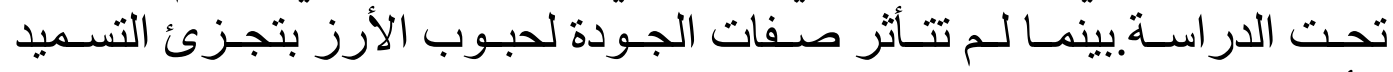

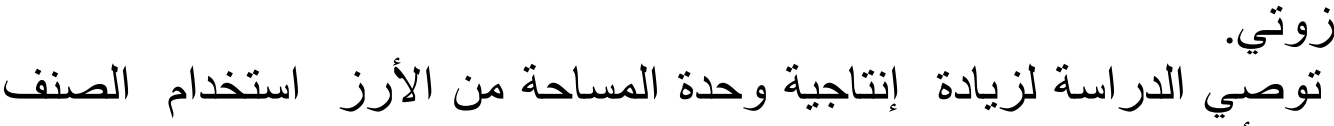

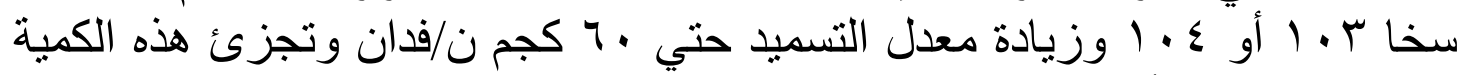

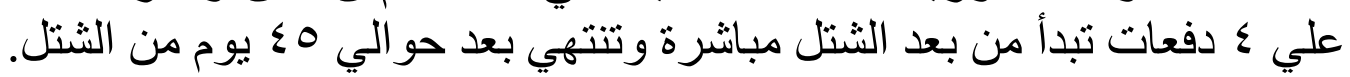

